\title{
Two-Pass Weed Management with Preemergence and Postemergence Herbicides in Glyphosate-Resistant Soybean
}

\author{
Nader Soltani ${ }^{*}$, Robert E. Nurse ${ }^{2}$, Peter H. Sikkema1 \\ ${ }^{1}$ University of Guelph Ridgetown Campus, Ridgetown, Canada \\ ${ }^{2}$ Agriculture and Agri-Food Canada, Harrow, Canada \\ Email: ${ }^{*}$ soltani@uoguelph.ca
}

Received 20 March 2014; revised 25 April 2014; accepted 12 May 2014

Copyright (C) 2014 by authors and Scientific Research Publishing Inc.

This work is licensed under the Creative Commons Attribution International License (CC BY).

http://creativecommons.org/licenses/by/4.0/

(c) (i) Open Access

\section{Abstract}

There is little information on the efficacy and profitability of two-pass weed control strategies in soybean when a preemergence (PRE) residual herbicide is followed by glyphosate applied late postemergence (LPOST) under Ontario, Canada environmental conditions. Ten field trials were conducted during 2011-2013 in Ontario, Canada to determine the level of weed control, yield and net returns of various preemergence/postemergence programs in glyphosate-resistant soybean. Crop injury was $2 \%$ or less with the herbicides evaluated except for chlorimuron + flumioxazin (PRE) and pyroxasulfone + flumioxazin (PRE) which caused $4 \%$ and $7 \%$ visible injury in soybean, respectively. A single application of glyphosate resulted in variable weed control $(73 \%-98 \%)$ while the sequential application of glyphosate provided excellent weed control $(98 \%-100 \%)$. The control of all weeds 8 WAA after the LPOST glyphosate application was equivalent regardless of the PRE herbicide applied (96\% - 100\%). Soybean yield was equivalent to the weed free control regardless of the PRE herbicide applied. Soybean yield was lower than the sequential application of glyphosate with chlorimuron or pyroxasulfone/flumioxazin PRE fb glyphosate LPOST. Generally net return with the two-pass programs was equivalent to the sequential application of glyphosate. Net returns were lower than the sequential application of glyphosate with chlorimuron or s-metolachlor + flumetsulam followed by glyphosate LPOST. Based on these results, a sequential application of glyphosate or a two-pass program of a preemergence residual herbicide followed by glyphosate LPOST are the preferred weed management programs in glyphosate-resistant soybean. The two-pass programs have the potential to reduce selection pressure for glyphosate-resistant weeds.

\footnotetext{
*Corresponding author.
}

How to cite this paper: Soltani, N., Nurse, R.E. and Sikkema, P.H. (2014) Two-Pass Weed Management with Preemergence and Postemergence Herbicides in Glyphosate-Resistant Soybean. Agricultural Sciences, 5, 504-512. 


\section{Keywords}

Biomass, Weed Density, Glyphosate, Profitability Analysis, Soybean

\section{Introduction}

Soybean [Glycine max (L.) Merr.] is an important crop in the province of Ontario, Canada that has been grown since 1893 [1]. Currently, soybean is the largest cash crop grown based on hectarage in the province surpassing corn [2]. In 2012, soybean growers planted nearly 1.05 million hectares and produced 3.4 million tonnes of soybean with a farm gate value of more than $\$ 1,750,000,000$ [3]. Intensive agronomic practices, including effective integrated weed management strategies are needed for sustainable, long-term production of this important field crop.

Most of the soybean grown in Ontario is glyphosate-resistant which has provided growers with additional weed management options with economic advantages [4]-[6]. Glyphosate-resistant soybean was first introduced in Canada in 1997 and the market share has increased steadily over the years. In 2012, about 72\% of the soybean hectares in Eastern Canada were planted to glyphosate-resistant cultivars and the percentage is expected to increase in the future [5] [7]. Glyphosate provides soybean growers with an efficacious herbicide option for the control of annual, biennial and perennial weeds, and a cost-effective weed management tactic that does not result in unacceptable risks to the environment [4].

The weed management strategies that can be utilized in glyphosate-resistant soybean include one application of glyphosate applied early (EPOST) or late postemergence (LPOST), a sequential application of glyphosate applied EPOST and LPOST, an EPOST tankmix application with glyphosate, and a sequential application of a preemergence (PRE) residual herbicide followed by glyphosate applied LPOST [8]-[11]. Relying exclusively on glyphosate for weed management may result in the selection of glyphosate-resistant weed biotypes [11]-[13]. Selection pressure can be reduced with tankmixes or sequential applications that utilize more than one herbicide mode of action [11].

Studies have shown that a single-pass herbicide program with no residual activity can result in weed escapes and poor control of late emerging weeds [14] [15]. The sequential application of PRE herbicide such as s-metolachlor + metribuzin, metribuzin + imazethapyr, cloransulam-methyl, or sulfentrazone followed by glyphosate LPOST have potential to improve weed control in glyphosate-resistant soybean [8] [9] [14]-[18].

There is a demand on growers to maintain herbicide stewardship and produce economically sustainable crops that are competitive in the global market [19]. To achieve this goal, data on weed control, crop yield, and profitability of various weed management strategies are required to help identify the most advantageous herbicide program. Research has shown that growers must consistently get acceptable weed control and an increase in profitability for them to implement any new weed management strategy. The viability for various weed management programs needs to be assessed based on profit margins over weed control costs.

There is little information on the efficacy and profitability of two-pass weed control strategies in soybean when a PRE residual herbicide is followed by glyphosate applied LPOST under Ontario, Canada environmental conditions. Therefore, the objectives of this study were to determine the level of weed control, yield and net returns of various PRE/POST programs in glyphosate-resistant soybean.

\section{Materials and Methods}

\subsection{Study Establishment}

A total of ten field trials were conducted in Southwestern Ontario at the Greenhouse and Processing Crops Research Centre, Agriculture and Agri-Food Canada, Harrow, at the Huron Research Station, Exeter, Ontario and at the University of Guelph, Ridgetown Campus, Ridgetown, Ontario during 2011, 2012 and 2013. The soils ranged from Fox sandy loam to Brookston clay loam with $33 \%-82 \%$ sand, $5 \%-41 \%$ silt, $15 \%-29 \%$ clay, and $\mathrm{pH}$ of 6.0 - 7.9. Site preparation included moldboard plowing or disking in the autumn followed by two passes with a field cultivator with rolling basket harrows in the spring.

Experiments were arranged in a randomized complete block design with four replicates. There were a total of 
sixteen treatments: 1) Weedy control; 2) Weed-free control; 3) Glyphosate (EPOST); 4) Glyphosate (LPOST); 5) Glyphosate fb glyphosate (EPOST fb LPOST); 6) Imazethapyr/saflufenacil fb glyphosate (PRE fb LPOST); 7) Imazethapyr + metribuzin fb glyphosate (PRE fb LPOST); 8) Saflufenacil/DMTA-p fb glyphosate (PRE fb LPOST); 9) S-metolachlor + flumetsulam fb glyphosate (PRE fb LPOST); 10) S-metolachlor + flumetsulam + metribuzin fb glyphosate (PRE fb LPOST); 11) Chlorimuron fb glyphosate (PRE fb LPOST); 12) Chlorimuron + flumioxazin fb glyphosate (PRE fb LPOST); 13) S-metolachlor + metribuzin fb glyphosate (PRE fb LPOST); 14) S-metolachlor/metribuzin fb glyphosate (PRE fb LPOST); 15) Flumioxazin fb glyphosate (PRE fb LPOST); and 16) Pyroxasulfone + flumioxazin fb glyphosate (PRE fb LPOST). Application doses selected were based on the manufacturers recommended dose for each herbicide in Ontario and are listed in Table 4 and Table 5.

All plots were $3 \mathrm{~m}$ (4 soybean rows spaced $75 \mathrm{~cm}$ apart) wide and $8 \mathrm{~m}$ long at Harrow and Ridgetown and 10 $\mathrm{m}$ long at Exeter. Glyphosate-resistant soybean cultivars were seeded at a density of 500,000 seeds $\cdot \mathrm{ha}^{-1}$. Herbicides were applied using a $\mathrm{CO}_{2}$-pressurized sprayer calibrated to deliver $222 \mathrm{~L} \cdot \mathrm{ha}^{-1}$ aqueous solution at $210 \mathrm{kPa}$ at Harrow, $200 \mathrm{~L} \cdot \mathrm{ha}^{-1}$ aqueous solution at $241 \mathrm{kPa}$ at Exeter and $200 \mathrm{~L} \cdot \mathrm{ha}^{-1}$ aqueous solution at $207 \mathrm{kPa}$ at Ridgetown. The boom was $1.5 \mathrm{~m}$ wide with four ultra-low drift nozzles (ULD120-02, Hypro, New Brighton, $\mathrm{MN}$ ) spaced $50 \mathrm{~cm}$ apart. PRE treatments were applied $0-7$ days after seeding, EPOST treatments were applied at 1 - 2 trifoliate leaf stage and the LPOST treatments were applied at 5 - 6 trifoliate leaf stage.

Crop injury was evaluated visually 2 and 3 weeks after emergence (WAE), using a scale of 0 to $100 \%$ where a rating of 0 was defined as no visible plant injury and a rating of 100 was defined as plant death. Percent weed control was visually assessed 4 and 8 weeks after the LPOST herbicide application (WAA) using a scale of 0 to $100 \%$ where a rating of 0 was defined as no weed control and a rating of 100 was defined as complete control. Weed density and biomass (shoot dry weight) were evaluated at approximately 3 WAE (prior to LPOST glyphosate application) by counting and cutting plants at the soil surface in two $0.5 \mathrm{~m}^{2}$ quadrats per plot and separating by species. Plants were dried at $60^{\circ} \mathrm{C}$ to a constant moisture and then weighed. Soybean was mechanically harvested at physiological maturity using a plot combine at all sites. Soybean yields were adjusted to a $13.0 \%$ seed moisture content level.

\subsection{Statistical Analyses}

All data were subjected to analysis of variance and analyzed using the PROC MIXED procedure in SAS statistical software (Version 9.2. SAS Institute, Inc., Box 8000, SAS Circle, Cary, NC 27512). Variances were partitioned into the fixed effect of herbicide treatment and into the random effects of environment (year and location). When there were no significant interactions between environment and herbicide treatment the data were pooled and averaged. The assumptions of the variance analysis were tested by ensuring that the residuals were random, homogeneous, with a normal distribution about a mean of zero using residual plots and a Shapiro-Wilk normality test. All percentage data required an arcsine square root transformation. Yield data did not require transformation. All percentage data presented in tables are on the back-transformed scale. Treatment means were separated at the 5\% level of significance using Fisher's Protected LSD test.

\subsection{Profitability Analysis}

The profitability analysis is based on the level of profit margins over weed control costs, measured as gross income less herbicide and application costs. Gross income for each treatment was calculated as the yield multiplied by the cash price of soybean on October 1 of 2011, 2012 and 2013 at Chatham, ON and the herbicide costs for each treatment are based on the herbicide prices reported by AGRIS (AGRIS Co-operative Ltd., 835 Park Avenue West, Chatham, ON N7M 5J6, Canada) in 2011, 2012 and 2013. Application costs are determined based on cost of production data reported by the Ontario Ministry of Agriculture, Food and Rural Affairs (Field Crop Budgets, Publication 60, updated annually; Ontario Ministry of Agriculture, Food and Rural Affairs, 1 Stone Road West, Guelph, ON N1G 4Y2, Canada). All other costs of production are assumed to be constant across treatments, thus they are not considered in the analysis. Pairwise comparisons were made between treatments to test for significant differences in average profit margins between treatments. These pairwise comparisons are made across all locations and years as well as for each location in each year.

\section{Results and Discussion}

The dominant weed species in this study were velvetleaf (Abutilon theophrasti Medic., ABUTH), redroot pig- 
weed (Amaranthus retroflexus L., AMARE), common ragweed (Ambrosia artemisiifolia L., AMBEL), common lambsquarters (Chenopdium album L., CHEAL), barnyard grass (Echinochloa crus-galli, ECHCG), and green foxtail (Setaria viridis L., SETVI). There was no significant interaction between environments and treatments, therefore these data were pooled and averaged over environments.

\subsection{Weed Density and Biomass Prior to In-Crop Glyphosate Application}

One early postemergence application of glyphosate reduced density of ABUTH $67 \%$, AMARE 71\%, AMBEL 86\%, CHEAL 93\%, ECHCG 77\%, and SETVI 90\% compared to the weedy control (Table 1). The PRE herbicides reduced the density of ABUTH 42\% - 97\%, AMARE 68\% - 96\%, AMBEL 62\% - 90\%, CHEAL 79\% $97 \%$, ECHCG 77\% - 97\%, and SETVI 62\% - 96\% compared to the weedy control.

Weed biomass was similar to weed density for the various herbicide treatments evaluated (Table 1). One early postemergence application of glyphosate reduced biomass of ABUTH 77\%, AMARE 98\%, AMBEL 93\%, CHEAL 97\%, ECHCG 93\%, and SETVI 98\% compared to the weedy control (Table 1). The PRE herbicides reduced the biomass of ABUTH 55\% - 98\%, AMARE 78\% - 100\%, AMBEL 44\% - 78\%, CHEAL 27\% - 100\%, ECHCG $68 \%$ - 99\%, and SETVI 74\% - 98\% compared to the weedy control.

Based on weed density and biomass results, S-metolachlor/metribuzin is weak on ABUTH, AMARE and AMBEL; chlorimuron and flumioxazin are weak on AMBEL, ECHCG and SETVI; saflufenacil/dimethenamid-p is weak on CHEAL, ECHCG and SETVI; saflufenacil/imazethapyr is weak on ECHCG and SETVI; and imazethapyr + metribuzin is weak on ECHCG.

\subsection{Weed Control Prior to In-Crop Glyphosate Application}

At approximately $3 \mathrm{WAE}$, one EPOST application of glyphosate prior to the LPOST application of glyphosate controlled ABUTH 90\%, AMARE 89\%, AMBEL 89\%, CHEAL 92\%, ECHCG 93\%, and SETVI 94\% (Table 2). Imazethapyr/saflufenacil, imazethapyr + metribuzin, s-metolachlor + flumetsulam, s-metolachlor + flumetsulam + metribuzin, and chlorimuron + flumioxacin provided $90 \%-99 \%$ control of ABUTH, AMARE and CHEAL and provided $26 \%-88 \%$ control of AMBEL, ECHCG, and SETVI. Except for the flumioxazin and

Table 1. Mean density (no. $\left.\mathrm{m}^{-2}\right)$ and biomass $\left(\mathrm{g} \cdot \mathrm{m}^{-2}\right)$ of various weeds in response to weed management strategies approximately 3 weeks after emergence (prior to the in-crop application of glyphosate) in ten field trials conducted at Exeter, Harrow and Ridgetown, ON, Canada during 2011 to $2013^{\mathrm{a}, \mathrm{b}}$.

\begin{tabular}{|c|c|c|c|c|c|c|c|c|c|c|c|c|}
\hline \multirow[t]{3}{*}{ Treatment } & \multicolumn{2}{|c|}{ ABUTH } & \multicolumn{2}{|c|}{ AMARE } & \multicolumn{2}{|c|}{ AMBEL } & \multicolumn{2}{|c|}{ CHEAL } & \multicolumn{2}{|c|}{ ECHCG } & \multicolumn{2}{|c|}{ SETVI } \\
\hline & Density & Biomass & Density & Biomass & Density & Biomass & Density & Biomass & Density & Biomass & Density & Biomass \\
\hline & $\# / \mathrm{m}^{2}$ & $\mathrm{~g} / \mathrm{m}^{2}$ & $\# / \mathrm{m}^{2}$ & $\mathrm{~g} / \mathrm{m}^{2}$ & $\# / \mathrm{m}^{2}$ & $\mathrm{~g} / \mathrm{m}^{2}$ & $\# / \mathrm{m}^{2}$ & $\mathrm{~g} / \mathrm{m}^{2}$ & $\# / \mathrm{m}^{2}$ & $\mathrm{~g} / \mathrm{m}^{2}$ & $\# / \mathrm{m}^{2}$ & $\mathrm{~g} / \mathrm{m}^{2}$ \\
\hline 1 weedy & $12 \mathrm{a}$ & $3.3 \mathrm{a}$ & $28 \mathrm{a}$ & $8.7 \mathrm{a}$ & $29 a$ & $19.3 \mathrm{a}$ & $29 a$ & $6.7 \mathrm{a}$ & $30 \mathrm{a}$ & $15.0 \mathrm{a}$ & $79 a$ & $29.0 \mathrm{a}$ \\
\hline 3 & $4 \mathrm{c}$ & $0.77 \mathrm{c}$ & $8 b$ & $0.2 \mathrm{~b}$ & $4 \mathrm{c}$ & $1.3 \mathrm{~d}$ & $2 d$ & $0.2 \mathrm{~b}$ & $7 \mathrm{de}$ & $1.0 \mathrm{~b}$ & $8 \mathrm{de}$ & $0.7 \mathrm{~b}$ \\
\hline 6 & $1 \mathrm{c}$ & $0.22 \mathrm{c}$ & $1 d$ & $0.02 b$ & $4 c$ & $4.5 \mathrm{~cd}$ & $1 \mathrm{~d}$ & $0.09 \mathrm{~b}$ & $8 \mathrm{~d}$ & $1.4 \mathrm{~b}$ & $16 \mathrm{c}$ & $1.9 \mathrm{~b}$ \\
\hline 7 & $1 \mathrm{c}$ & $0.06 \mathrm{c}$ & $1 d$ & $0.06 \mathrm{~b}$ & $5 \mathrm{c}$ & $4.7 \mathrm{~cd}$ & $1 d$ & $0.03 b$ & $9 \mathrm{~cd}$ & $0.9 \mathrm{~b}$ & $5 \mathrm{e}$ & $0.5 b$ \\
\hline 8 & $3 c$ & $0.7 \mathrm{c}$ & $3 d$ & $1.9 \mathrm{~b}$ & $5 c$ & $5.0 \mathrm{~cd}$ & $6 \mathrm{c}$ & $4.9 \mathrm{a}$ & $12 \mathrm{c}$ & $3.7 b$ & $19 \mathrm{c}$ & $7.6 \mathrm{~b}$ \\
\hline 9 & $2 \mathrm{c}$ & $0.3 \mathrm{c}$ & $4 \mathrm{~cd}$ & $1.3 b$ & $10 \mathrm{~b}$ & $6.8 \mathrm{bc}$ & $1 d$ & $0.3 b$ & $5 \mathrm{e}$ & $1.3 b$ & $8 \mathrm{de}$ & $3.9 \mathrm{~b}$ \\
\hline 10 & $1 \mathrm{c}$ & $0.2 \mathrm{c}$ & $2 d$ & $0.07 b$ & $5 \mathrm{c}$ & $4.7 \mathrm{~cd}$ & $1 d$ & $0.04 \mathrm{~b}$ & $4 \mathrm{e}$ & $0.6 \mathrm{~b}$ & $4 \mathrm{ef}$ & $2.5 \mathrm{~b}$ \\
\hline 11 & $2 \mathrm{c}$ & $0.6 \mathrm{c}$ & $1 d$ & $0.3 b$ & $10 \mathrm{~b}$ & $8.1 \mathrm{~b}$ & $1 d$ & $0.2 \mathrm{~b}$ & $22 b$ & $2.9 \mathrm{~b}$ & $30 \mathrm{~b}$ & $5.7 b$ \\
\hline 12 & $1 \mathrm{c}$ & $0.3 \mathrm{c}$ & $1 d$ & $0.008 \mathrm{~b}$ & $5 \mathrm{c}$ & $4.5 \mathrm{~cd}$ & $1 d$ & $0.1 b$ & $13 \mathrm{c}$ & $4.3 b$ & $12 \mathrm{c}$ & $5.6 \mathrm{~b}$ \\
\hline 13 & $4 c$ & $1.5 \mathrm{bc}$ & $6 \mathrm{bc}$ & $1.1 \mathrm{~b}$ & $11 \mathrm{~b}$ & $7.5 \mathrm{bc}$ & $1 d$ & $0.4 \mathrm{~b}$ & $4 \mathrm{e}$ & $1.0 \mathrm{~b}$ & $5 \mathrm{ef}$ & $4.7 \mathrm{~b}$ \\
\hline 14 & $7 b$ & $2.7 \mathrm{a}$ & $9 b$ & $0.6 \mathrm{~b}$ & $10 \mathrm{~b}$ & $8.1 \mathrm{~b}$ & $2 d$ & $0.6 \mathrm{~b}$ & $1 \mathrm{e}$ & $0.1 b$ & $3 \mathrm{f}$ & $0.9 \mathrm{~b}$ \\
\hline 15 & $2 \mathrm{c}$ & $0.4 \mathrm{c}$ & $1 d$ & $0.09 b$ & $9 b$ & $10.8 \mathrm{~b}$ & $2 d$ & $0.3 b$ & $11 \mathrm{~cd}$ & $4.8 \mathrm{~b}$ & $10 \mathrm{c}$ & $6.1 \mathrm{~b}$ \\
\hline 16 & $1 \mathrm{c}$ & $0.2 \mathrm{c}$ & $1 d$ & $0.02 \mathrm{~b}$ & $3 c$ & $4.2 \mathrm{~cd}$ & $1 \mathrm{~d}$ & $0.2 \mathrm{~b}$ & $4 \mathrm{e}$ & $1.4 \mathrm{~b}$ & $4 \mathrm{ef}$ & $2.0 \mathrm{~b}$ \\
\hline
\end{tabular}

${ }^{a}$ Abbreviations: ABUTH, velvetleaf; AMARE, redroot pigweed; AMBEL, common ragweed; CHEAL, common lambsquarters; ECHCG, barnyardgrass; and SETVI, green foxtail. ${ }^{b}$ Data were averaged for environments. Means followed by the same letter within a column are not significantly different according to Fisher's Protected LSD $(\mathrm{P}<0.05)$. Treatment 4 was removed as there was no herbicide applied at this point. Treatment 5 was also removed since at this point in the season it was a repeat of Treatment 3 . 
Table 2. Mean control (\%) of various weeds in response to weed management strategies 3 weeks after emergence (prior to the in-crop application of glyphosate) in ten field trials conducted at Exeter, Harrow and Ridgetown, ON, Canada during 2011 to $2013^{\mathrm{a}, \mathrm{b}}$.

\begin{tabular}{ccccccc}
\hline Treatment & ABUTH & AMARE & AMBEL & CHEAL & ECHCG & SETVI \\
\hline 3 & $90 \mathrm{a}$ & $89 \mathrm{ab}$ & $89 \mathrm{a}$ & $92 \mathrm{a}$ & $93 \mathrm{a}$ & $94 \mathrm{a}$ \\
6 & $98 \mathrm{a}$ & $98 \mathrm{a}$ & $78 \mathrm{bc}$ & $95 \mathrm{a}$ & $44 \mathrm{de}$ & $76 \mathrm{c}$ \\
7 & $98 \mathrm{a}$ & $99 \mathrm{a}$ & $78 \mathrm{bc}$ & $96 \mathrm{a}$ & $80 \mathrm{bc}$ & $88 \mathrm{~b}$ \\
8 & $30 \mathrm{~d}$ & $56 \mathrm{~d}$ & $47 \mathrm{e}$ & $55 \mathrm{~d}$ & $33 \mathrm{e}$ & $45 \mathrm{e}$ \\
9 & $98 \mathrm{a}$ & $91 \mathrm{ab}$ & $62 \mathrm{~d}$ & $90 \mathrm{ab}$ & $76 \mathrm{c}$ & $76 \mathrm{c}$ \\
10 & $97 \mathrm{a}$ & $99 \mathrm{a}$ & $78 \mathrm{bc}$ & $95 \mathrm{a}$ & $83 \mathrm{~b}$ & $84 \mathrm{bc}$ \\
11 & $53 \mathrm{c}$ & $87 \mathrm{~b}$ & $59 \mathrm{de}$ & $78 \mathrm{c}$ & $5 \mathrm{~g}$ & $26 \mathrm{f}$ \\
12 & $90 \mathrm{a}$ & $99 \mathrm{a}$ & $78 \mathrm{bc}$ & $95 \mathrm{a}$ & $26 \mathrm{ef}$ & $62 \mathrm{~d}$ \\
13 & $31 \mathrm{~d}$ & $88 \mathrm{bc}$ & $58 \mathrm{de}$ & $84 \mathrm{bc}$ & $86 \mathrm{~b}$ & $81 \mathrm{bc}$ \\
14 & $29 \mathrm{~d}$ & $84 \mathrm{c}$ & $47 \mathrm{e}$ & $78 \mathrm{c}$ & $92 \mathrm{ab}$ & $82 \mathrm{bc}$ \\
15 & $59 \mathrm{c}$ & $90 \mathrm{ab}$ & $52 \mathrm{e}$ & $76 \mathrm{c}$ & $19 \mathrm{f}$ & $40 \mathrm{e}$ \\
\hline
\end{tabular}

a Abbreviations: ABUTH, velvetleaf; AMARE, redroot pigweed; AMBEL, common ragweed; CHEAL, common lambsquarters; ECHCG, barnyardgrass; and SETVI, green foxtail. ${ }^{b}$ Data were averaged for environments. Means followed by the same letter within a column are not significantly different according to Fisher's Protected LSD $(\mathrm{P}<0.05)$. Treatment 4 was removed as there was no herbicide applied at this point. Treatment 5 was also removed since at this point in the season it was a repeat of Treatment 3.

pyroxasulfone + flumioxazin which provided $90 \%$ - 98\% control of AMARE and s-metolachlor/metribuzin which provided $92 \%$ control of ECHCG other PRE herbicides evaluated provided less than adequate control $(5 \%-88 \%)$ of dominant weed species in this study (Table 2). This is similar to other studies [18] that have found $4 \%-47 \%$ control of ABUTH, $47 \%$ - $62 \%$ control of AMARE, $17 \%$ - 27\% control of AMBEL, $41 \%$ $70 \%$ control of CHEAL, and 37\% - 49\% control of SETVI with PRE herbicides such as imazethapyr, s-metolachlor/benoxacor + metribuzin and flumetsulam/s-metolachlor.

\subsection{Weed Control after In-Crop Glyphosate Application}

Data for weed control at 4 and 8 WAA were similar; therefore only data for 8 WAA are presented (Table 3). One EPOST application of glyphosate controlled ABUTH 79\%, AMARE 73\%, AMBEL 81\%, CHEAL 84\%, ECHCG 72\%, and SETVI 80\%. One LPOST application of glyphosate controlled ABUTH 87\%, AMARE 98\%, AMBEL 88\%, CHEAL 92\%, ECHCG 91\%, and SETVI 95\%. The sequential application of glyphosate (EPOST fb LPOST) improved efficacy and controlled ABUTH 100\%, AMARE 99\%, AMBEL 98\%, CHEAL 99\%, ECHCG $100 \%$, and SETVI $99 \%$. The sequential application of a preemergence herbicide followed by an application of glyphosate LPOST controlled ABUTH 99\% - 100\%, AMARE 99\% - 100\%, AMBEL 96\% - 98\%, CHEAL 99\% - 100\%, ECHCG 97\% - 100\%, and SETVI 99\% - 100\% which was equivalent to the sequential application of glyphosate.

Results are similar to other studies [18] that have shown that the sequential application of PRE herbicides such as imazethapyr, s-metolachlor + metribuzin and flumetsulam/s-metolachlor followed by an application of glyphosate LPOST controlled ABUTH 78\% - 100\%, AMARE 99\% - 100\%, AMBEL 91\% - 94\%, CHEAL 97\% $-98 \%$, and SETVI $99 \%-100 \%$. The same study also showed that the sequential application of glyphosate (EPOST fb LPOST) provided 100\% control of ABUTH, AMARE, AMBEL, CHEAL, and SETVI [18]. Similarly Gonzini et al. [16] found that the sequential application of PRE herbicide chlorimuron + metribuzin, cloransulam-methyl, or sulfentrazone followed by glyphosate improved weed control compared to a single application of glyphosate although weed control was not superior to the sequential applications of glyphosate. The study showed that the sequential glyphosate applications increased common lambsquarters control $4 \%-9 \%$ in soybean compared to a single application of glyphosate [16]. Gonzini et al. [16] also found $13 \%-22 \%$ and $17 \%$ - $27 \%$ increase in velvetleaf control compared to a single application of glyphosate when PRE herbicides were followed by glyphosate or sequential applications of glyphosate were applied, respectively. Similarly, giant foxtail control improved 2\% - 15\% with sequential applications of glyphosate POST or PRE herbicides followed by 
Table 3. Mean control (\%) of various weeds in response to weed management strategies 8 WAA (after in-crop application of glyphosate) in ten field trials conducted at Exeter, Harrow and Ridgetown, ON, Canada during 2011 to 2013 (data averaged over environments) ${ }^{\mathrm{a}}$.

\begin{tabular}{ccccccc}
\hline Treatment & ABUTH & AMARE & AMBEL & CHEAL & ECHCG & SETVI \\
\hline 3 & $79 \mathrm{~b}$ & $73 \mathrm{~b}$ & $81 \mathrm{~b}$ & $84 \mathrm{~b}$ & $72 \mathrm{~b}$ & $80 \mathrm{~b}$ \\
4 & $87 \mathrm{~b}$ & $98 \mathrm{a}$ & $88 \mathrm{~b}$ & $92 \mathrm{a}$ & $91 \mathrm{ab}$ & $95 \mathrm{a}$ \\
5 & $100 \mathrm{a}$ & $99 \mathrm{a}$ & $98 \mathrm{a}$ & $99 \mathrm{a}$ & $100 \mathrm{a}$ & $99 \mathrm{a}$ \\
6 & $100 \mathrm{a}$ & $100 \mathrm{a}$ & $97 \mathrm{a}$ & $100 \mathrm{a}$ & $100 \mathrm{a}$ & $100 \mathrm{a}$ \\
7 & $100 \mathrm{a}$ & $100 \mathrm{a}$ & $98 \mathrm{a}$ & $100 \mathrm{a}$ & $99 \mathrm{a}$ & $100 \mathrm{a}$ \\
8 & $99 \mathrm{a}$ & $100 \mathrm{a}$ & $98 \mathrm{a}$ & $100 \mathrm{a}$ & $97 \mathrm{a}$ & $99 \mathrm{a}$ \\
9 & $100 \mathrm{a}$ & $100 \mathrm{a}$ & $97 \mathrm{a}$ & $100 \mathrm{a}$ & $99 \mathrm{a}$ & $100 \mathrm{a}$ \\
10 & $100 \mathrm{a}$ & $100 \mathrm{a}$ & $98 \mathrm{a}$ & $100 \mathrm{a}$ & $100 \mathrm{a}$ & $100 \mathrm{a}$ \\
11 & $99 \mathrm{a}$ & $100 \mathrm{a}$ & $97 \mathrm{a}$ & $99 \mathrm{a}$ & $97 \mathrm{a}$ & $99 \mathrm{a}$ \\
12 & $100 \mathrm{a}$ & $100 \mathrm{a}$ & $98 \mathrm{a}$ & $100 \mathrm{a}$ & $98 \mathrm{a}$ & $100 \mathrm{a}$ \\
13 & $100 \mathrm{a}$ & $99 \mathrm{a}$ & $96 \mathrm{a}$ & $100 \mathrm{a}$ & $99 \mathrm{a}$ & $100 \mathrm{a}$ \\
14 & $99 \mathrm{a}$ & $100 \mathrm{a}$ & $97 \mathrm{a}$ & $100 \mathrm{a}$ & $99 \mathrm{a}$ & $100 \mathrm{a}$ \\
15 & $100 \mathrm{a}$ & $100 \mathrm{a}$ & $96 \mathrm{a}$ & $99 \mathrm{a}$ & $96 \mathrm{a}$ & $99 \mathrm{a}$ \\
\hline
\end{tabular}

aAbbreviations: ABUTH, velvetleaf; AMARE, redroot pigweed; AMBEL, common ragweed; CHEAL, common lambsquarters; ECHCG, barnyardgrass; and SETVI, green foxtail. ${ }^{b}$ Data were averaged for environments. Means followed by the same letter within a column are not significantly different according to Fisher's Protected LSD $(\mathrm{P}<0.05)$.

a POST application of glyphosate compared to a single-pass application of glyphosate POST [16].

\subsection{Crop Injury and Yield}

At 2 weeks after emergence (WAE) chlorimuron + flumioxacin fb glyphosate (PRE fb LPOST); s-metolachlor + metribuzin fb glyphosate (PRE fb LPOST); s-metolachlor/metribuzin fb glyphosate (PRE fb LPOST); flumioxazin fb glyphosate (PRE fb LPOST); and pyroxasulfone + flumioxazin fb glyphosate (PRE fb LPOST) caused $4 \%, 2 \%, 2 \%, 4 \%$, and $7 \%$ injury in soybean, respectively (Table 4 ). However, there was no injury with other treatments evaluated. At 3 WAE, no significant visible injury resulted from the herbicide treatments evaluated except for pyroxasulfone + flumioxazin which caused 3\% injury in soybean. Other studies have also shown transient crop injury with pyroxasulfone + flumioxazin in soybean [20]-[24].

Reduced weed interference by the herbicide treatments evaluated resulted in an increase soybean yield of 1.2 to $1.6 \mathrm{t} \cdot \mathrm{ha}^{-1}$ compared to non-treated weedy control (Table 5). There was no adverse effect on soybean yield with glyphosate applied EPOST, LPOST and the sequential glyphosate applications (EPOST fb LPOST) compared to the weed free control (Table 5). Soybean yield was equivalent to the weed free control regardless of the PRE herbicide fb glyphosate applied. Soybean yield was lower than the sequential application of glyphosate with chlorimuron or pyroxasulfone/flumioxazin fb glyphosate (Table 5). Other studies that have shown lower soybean yield with PRE application of pyroxasulfone/flumioxazin, flumioxazin, pyroxasulfone, s-metolachlor + metribuzin, flumioxazin + imazethapyr + metribuzin, dimethenamid-p + imazethapyr + metribuzin, and s-metholachlor + metribuzin + chlorimuron compared to the weed-free control [20]. In other studies, soybean yields were not significantly different between the glyphosate EPOST alone or tank-mixed combination with imazethapyr, sequential applications of glyphosate, s-metolachlor + metribuzin followed by glyphosate and flumetsulam/s-metolachlor followed by glyphosate treatments [18]. Swanton et al. [25] also found no significant differences in soybean yield between sequential applications of glyphosate and glyphosate + imazethapyr.

\subsection{Profitability Analysis}

Profitability analysis indicated that weeds decreased profit margin $688 \mathrm{CAN} \$ \mathrm{ha}^{-1}$ compared to the weed-free control (Table 5). Herbicide treatments increased profit margin 535 to 677 CAN $\$$ ha $^{-1}$ compared to the non- 
Table 4. Mean soybean injury with various weed management strategies used in ten field trials conducted at Exeter, Harrow, and Ridgetown, ON, Canada during 2011 to $2013^{\mathrm{a}, \mathrm{b}}$.

\begin{tabular}{|c|c|c|c|c|}
\hline \multirow{2}{*}{ Treatment } & \multirow{2}{*}{ Timing } & \multirow{2}{*}{$\begin{array}{c}\text { Herbicide Rate } \\
\left(\mathrm{g} \text { ai } / \mathrm{ae} \cdot \mathrm{ha}^{-1}\right)\end{array}$} & \multicolumn{2}{|c|}{ Crop Injury } \\
\hline & & & $2 \mathrm{WAE}$ & $3 \mathrm{WAE}$ \\
\hline 1. Weedy & & & $0 \mathrm{e}$ & $0 \mathrm{~b}$ \\
\hline 2. Weed-free & & & $0 \mathrm{e}$ & $0 \mathrm{~b}$ \\
\hline 3. Glyphosate (early) & EPOST & 900 & $0 \mathrm{e}$ & $0 \mathrm{~b}$ \\
\hline 4. Glyphosate (late) & LPOST & 900 & $0 \mathrm{e}$ & $0 \mathrm{~b}$ \\
\hline 5. Glyphosate fb glyphosate & EPOST fb LPOST & $900 \mathrm{fb} 900$ & $0 \mathrm{e}$ & $0 \mathrm{~b}$ \\
\hline 6. imazethapyr/saflufenacil fb glyphosate & PRE fb LPOST & $75 \mathrm{fb} 900$ & $0 \mathrm{e}$ & $0 \mathrm{~b}$ \\
\hline 7. imazethapyr + metribuzin fb glyphosate & PRE fb LPOST & $75+425 \mathrm{fb} 900$ & $0 \mathrm{e}$ & $0 \mathrm{~b}$ \\
\hline 8. saflufenacil/DMTA-p fb glyphosate & PRE fb LPOST & $245 \mathrm{fb} 900$ & $0 \mathrm{e}$ & $0 \mathrm{~b}$ \\
\hline 9. s-metolachlor + flumetsulam fb glyphosate & PRE fb LPOST & $1050+35 \mathrm{fb} 900$ & $1 \mathrm{de}$ & $0 \mathrm{~b}$ \\
\hline 10. s-metolachlor + flumetsulam + metribuzin fb glyphosate & PRE fb LPOST & $800+35+327$ fb 900 & $1 \mathrm{de}$ & $0 \mathrm{~b}$ \\
\hline 11. chlorimuron fb glyphosate & PRE fb LPOST & $9 \mathrm{fb} 900$ & $0 \mathrm{e}$ & $2 \mathrm{ab}$ \\
\hline 12. chlorimuron + flumioxacin fb glyphosate & PRE fb LPOST & $9+71.4 \mathrm{fb} 900$ & $4 \mathrm{~b}$ & $3 a$ \\
\hline 13. s-metolachlor + metribuzin fb glyphosate & PRE fb LPOST & $1050+430 \mathrm{fb} 900$ & $2 \mathrm{~cd}$ & $0 \mathrm{~b}$ \\
\hline 14. s-metolachlor/metribuzin fb glyphosate & PRE fb LPOST & $1700 \mathrm{fb} 900$ & $2 \mathrm{~cd}$ & $0 \mathrm{~b}$ \\
\hline 15. flumioxazin fb glyphosate & PRE fb LPOST & $71.4 \mathrm{fb} 900$ & $4 \mathrm{~b}$ & $1 \mathrm{ab}$ \\
\hline 16. Pyroxasulfone + flumioxazin fb glyphosate & PRE fb LPOST & $199.9 \mathrm{fb} 900$ & $7 \mathrm{a}$ & $3 a$ \\
\hline
\end{tabular}

${ }^{a}$ Data were averaged for environments. Means followed by the same letter within a column are not significantly different according to Fisher's Protected LSD $(\mathrm{P}<0.05)$. ${ }^{\mathrm{b}}$ Abbreviations: EPOST, early postemergence; LPOST, late postemergence; fb, followed by.

Table 5. Mean soybean yield and profit margin of weed management strategies used in ten field trials conducted at Exeter, Harrow, and Ridgetown, ON, Canada during 2011 to $2013^{\mathrm{a}, \mathrm{b}}$.

\begin{tabular}{lcccc}
\hline & & Herbicide Rate & Yield & Profit \\
\cline { 3 - 5 } Treatment & Timing & $\left(\mathrm{g} \mathrm{ai} / \mathrm{ae}^{\left.-\mathrm{ha}^{-1}\right)}\right.$ & $\left(\mathrm{t} \cdot \mathrm{ha}^{-1}\right)$ & $\left(\mathrm{CAN} \$ \mathrm{~h}^{-1}\right)$ \\
\hline 1. Weedy & & & $2.6 \mathrm{~d}$ & $1230.73 \mathrm{~d}$ \\
2. Weed-free & & $4.0 \mathrm{abc}$ & $1918.34 \mathrm{a}$ \\
3. Glyphosate (early) & EPOST & 900 & $3.9 \mathrm{bc}$ & 18.15 .19 \\
4. Glyphosate (late) & LPOST & 900 & $3.8 \mathrm{c}$ & $1796.83 \mathrm{bc}$ \\
5. Glyphosate fb glyphosate & EPOST fb LPOST & $900 \mathrm{fb} 900$ & $4.2 \mathrm{a}$ & $1907.32 \mathrm{a}$ \\
6. imazethapyr/saflufenacil fb glyphosate & PRE fb LPOST & $75 \mathrm{fb} 900$ & $4.1 \mathrm{ab}$ & $1856.92 \mathrm{abc}$ \\
7. imazethapyr + metribuzin fb glyphosate & PRE fb LPOST & $75+425 \mathrm{fb} 900$ & $4.1 \mathrm{ab}$ & $1793.38 \mathrm{bc}$ \\
8. saflufenacil/DMTA-p fb glyphosate & PRE fb LPOST & $245 \mathrm{fb} 900$ & $4.1 \mathrm{ab}$ & $1865.88 \mathrm{abc}$ \\
9. s-metolachlor + flumetsulam fb glyphosate & PRE fb LPOST & $1050+35 \mathrm{fb} 900$ & $4.0 \mathrm{abc}$ & $1770.45 \mathrm{c}$ \\
10. s-metolachlor + flumetsulam + metribuzin fb glyphosate & PRE fb LPOST & $800+35+327 \mathrm{fb} 900$ & $4.1 \mathrm{ab}$ & $1824.45 \mathrm{abc}$ \\
11. chlorimuron fb glyphosate & PRE fb LPOST & $9 \mathrm{fb} 900$ & $3.9 \mathrm{bc}$ & $1765.48 \mathrm{c}$ \\
12. chlorimuron + flumioxacin fb glyphosate & PRE fb LPOST & $9+71.4 \mathrm{fb} 900$ & $4.1 \mathrm{ab}$ & $1801.34 \mathrm{abc}$ \\
13. s-metolachlor + metribuzin fb glyphosate & PRE fb LPOST & $1050+430 \mathrm{fb} 900$ & $4.1 \mathrm{ab}$ & $1833.26 \mathrm{abc}$ \\
14. s-metolachlor/metribuzin fb glyphosate & PRE fb LPOST & $1700 \mathrm{fb} 900$ & $4.0 \mathrm{abc}$ & - \\
15. flumioxazin fb glyphosate & PRE fb LPOST & $71.4 \mathrm{fb} 900$ & $4.0 \mathrm{abc}$ & $1816.23 \mathrm{abc}$ \\
16. Pyroxasulfone + flumioxazin fb glyphosate & PRE fb LPOST & $199.9 \mathrm{fb} 900$ & $3.9 \mathrm{bc}$ & -
\end{tabular}

${ }^{a}$ Data were averaged for environments. Means followed by the same letter within a column are not significantly different according to Fisher's Protected LSD $(\mathrm{P}<0.05)$. ${ }^{\mathrm{b}}$ Abbreviations: EPOST, early postemergence; LPOST, late postemergence; fb, followed by. 
treated weedy control (Table 5). There was no significant difference in profit margin between glyphosate applied EPOST (1815 CAN \$ ha ${ }^{-1}$ ) or LPOST (1797 CAN \$ ha ${ }^{-1}$ ). The sequential glyphosate application EPOST $\mathrm{fb}$ LPOST had a profit margin of 1907 CAN $\$ \mathrm{ha}^{-1}$ which was higher than a single application of glyphosate although results were not statistically significant (Table 5). Generally net return with the two-pass (PRE fb POST) programs was equivalent to the sequential application of glyphosate (EPOST fb LPOST). However, net returns were lower than the sequential application of glyphosate with chlorimuron or s-metolachlor + flumetsulam PRE followed by glyphosate LPOST (Table 5).

\section{Conclusions}

Based on results of this study, herbicide efficacy is specific weed species and the choice of PRE herbicide is dependent on historical field records. S-metolachlor/metribuzin provided poor control of velvetleaf, pigweed and ragweed. Chlorimuron and flumioxazin provided poor control of ragweed, barnyard grass and foxtail. Saflufenacil/dimethenamid-p provided poor control of lambsquarters, barnyard grass and foxtail. Saflufenacil/imazethapyr provided poor control of barnyard grass and foxtail. Imazethapyr + metribuzin provided poor control of barnyard grass.

A single application of glyphosate resulted in variable weed control (73\% - 98\%) while the sequential application of glyphosate provided excellent weed control $(98 \%-100 \%)$. Glyphosate was the great equalizer as the control of all weeds 8 WAA after the LPOST glyphosate application was equivalent regardless of the PRE herbicide applied $(96 \%-100 \%)$.

Soybean yield was equivalent to the weed free control regardless of the PRE herbicide applied. Soybean yield was lower than the sequential application of glyphosate with chlorimuron or pyroxasulfone/flumioxazin PRE fb glyphosate LPOST. Generally, net return with the two-pass programs was equivalent to the sequential application of glyphosate. Net returns were lower than the sequential application of glyphosate with chlorimuron or s-metolachlor + flumetsulam followed by glyphosate LPOST.

This study concludes that the most efficacious and profitable weed management programs in glyphosate resistant soybean are a sequential application of glyphosate or a two-pass program of a preemergence residual herbicide followed by glyphosate LPOST. The two-pass programs have the potential to reduce selection pressure for glyphosate-resistant weeds and therefore they have glyphosate stewardship benefits.

\section{Acknowledgements}

The authors would like to acknowledge the technical assistance of Lynette Brown, Todd Cowan, Elaine Lepp, and Christy Shropshire.

\section{References}

[1] Canadian Food Inspection Agency, CFIA (1996) The Biology of Glycine max (L.) Merr. (Soybean). Biology Document (BIO1996-10), Ottawa, 11.

[2] McGee, B. (2010) Estimated Area, Yield, Production and Farm Value of Specified Field Crops, Ontario, 2001-2010. Ontario Ministry of Agriculture and Food and Rural Affairs. http://www.omafra.gov.on.ca/english/stats/crops/estimate metric.html

[3] Kulasekera, K. (2014) Estimated Area, Yield, Production and Farm Value of Specified Field Crops, Ontario, 20112013 (Metric Units). Ontario Ministry of Agriculture, Food and Rural Affairs. http://www.omafra.gov.on.ca/english/stats/crops/estimate_new.htm

[4] Sikkema, P.H. and Soltani, N. (2007) Herbicide-Resistant Crops in Eastern Canada. In: Gulden, R.H. and Swanton, C.J., Eds., The First Decade of Herbicide-Resistant Crops in Canada. Topics in Canadian Weed Science, Volume 4 , Sainte Anne de Bellevue, Quebec.

[5] Sikkema, P.H., Robinson, D.E., Tardif, F.J., Lawton, M.B. and Soltani, N. (2013) Discovery of Glyphosate-Resistant Weeds in Ontario, Canada-Distribution plus Control. Global Herbicide Resistant Challenge Conference, Perth, 18-23 February 2013.

[6] Shurtleff, W. and Aoyagi, A. (2010) History of Soybeans and Soyfoods in Canada (1831-2010): Bibliography and Sourcebook. Soyinfo Center, Lafayette.

[7] Beckie, H.J., Sikkema, P.H., Soltani, N., Blackshaw, R.E. and Johnson, E.N. (2014) Environmental Impact of Glyphosate-Resistant Weeds in Canada. Weed Technology, 62, 385-392. http://dx.doi.org/10.1614/WS-D-13-00093.1 
[8] Barnes, J.W. and Oliver, L.R. (2004) Cloransulam Antagonizes Annual Grass Control with Aryloxyphenoxypropionate Graminicides but Not Cyclohexanediones. Weed Technology, 18, 763-772. http://dx.doi.org/10.1614/WT-03-181R

[9] Nurse, R.E., Hamill, A.S., Swanton, C.J., Tardif, F.J., Deen, W. and Sikkema, P.H. (2007) Is the Application of a Residual Herbicide Required Prior to Glyphosate Application in No-Till Glyphosate-Tolerant Soybean (Glycine max)? Crop Protection, 26, 484-489. http://dx.doi.org/10.1016/j.cropro.2006.04.018

[10] Stewart, C.L., Soltani, N., Nurse, R.E., Hamill, A.S. and Sikkema, P.H. (2012) Precipitation Influences Pre- and Postemergence Herbicide Efficacy in Corn. American Journal of Plant Sciences, 3, 1193-1204. http://dx.doi.org/10.4236/ajps.2012.39145

[11] Young, B.G. (2006) Changes in Herbicide Use Patterns and Production Practices Resulting from Glyphosate-Resistant Crops. Weed Technology, 20, 301-307. http://dx.doi.org/10.1614/WT-04-189.1

[12] Heap, I. (2014) The International Survey of Herbicide Resistant Weeds. http://www.weedscience.org

[13] Vink, J.P., Soltani, N., Robinson, D.E., Tardif, F.J., Lawton, M.B. and Sikkema, P.H. (2012) Occurrence and Distribution of Glyphosate-Resistant Giant Ragweed (Ambrosia trifida L.) in Southwestern Ontario. Canadian Journal of Plant Science, 92, 533-539. http://dx.doi.org/10.4141/cjps2011-249

[14] Hartzler B. (1996) Is One-Pass Weed Control a Realistic Goal? Department of Agronomy, Iowa State University Extension Agronomy, 3.

[15] Loux, M.M., Dobbels, A.F., Johnson, W.G., Nice, G.R.W., Bauman, T.T. and Stachler, J.M. (2008) Weed Control Guide for Ohio and Indiana. Ohio State University Extension Bulletin 789/Purdue Extension Pub, 201.

[16] Gonzini, L.C., Hart, S.E. and Wax, L.M. (1999) Herbicide Combinations for Weed Management in Glyphosate-Resistant Soybean (Glycine max). Weed Technology, 13, 354-360.

[17] Nelson, K.A. (2007) Glyphosate Application Timings in Twin- and Single-Row Corn and Soybean Spacings. Weed Technology, 21, 186-190. http://dx.doi.org/10.1614/WT-05-073.1

[18] Stewart, C.L., Nurse, R.E., Van Eerd, L.L., Vyn, R.V. and Sikkema, P.H. (2011) Weed Control, Environmental Impact and Economics of Weed Management Strategies in Glyphosate-Tolerant Soybean. Weed Technology, 25, 535-541. http://dx.doi.org/10.1614/WT-D-10-00116.1

[19] Brookes, G. and Barfoot, P. (2013) The Global Income and Production Effects of Genetically Modified (GM) Crops 1996-2011. GM Crops and Food: Biotechnology in Agriculture and Food Chain 4, 74-81. http://dx.doi.org/10.4161/gmcr.24176

[20] Mahoney, K.J., Shropshire, C. and Sikkema, P.H. (2014) Weed Management in Conventional- and No-Till Soybean (Glycine Max) with Flumioxazin/Pyrosasulfone. Weed Technology, 28, 298-306. http://dx.doi.org/10.1614/WT-D-13-00128.1

[21] Refsell, D.E., Ott, E.J., Dale, T.M. and Pawlak, J.A. (2009) V-10233 Performance in Midwest Soybean Fields. Proceedings of the North Central Weed Science Society, 7-10 December 2009, Kansas City.

[22] Stachler, J.M., Luecke, J.L. and Fisher, J.M. (2010) Controlling Glyphosate-Resistant Ragweed and Waterhemp with Preemergence Soybean Herbicides Having Safety to Sugarbeet in Rotation. Proceedings of the North Central Weed Science Society, Lexington, 13-16 December 2010.

[23] Stachler, J.M. and Luecke, J.L. (2011) The Utility of Preemergence Herbicides in Glufosinate-Resistant Soybean in a Sugarbeet Rotation in Minnesota and North Dakota. Proceedings of the North Central Weed Science Society, Milwaukee, 12-15 December 2011.

[24] Young, B.G., Bradley, K.W., Bernards, M.L., Hager, A.G., Hartzler, B.G., Johnson, W.G., Loux, M.M., Peterson, D., Sprague, C.L., Slack, C., Ott, E.J., Refsell, D., Dale, T.M., Cranmer, J.R., Kirfman, G.W. and Pawlak, J.A. (2010) Length of Residual Weed Control with V-10266 and Other Preemergence Soybean Herbicides. Proceedings of the North Central Weed Science Society, Lexington, 13-16 December 2010.

[25] Swanton, C.J., Shrestha, A., Chandler, K. and Deen, W. (2000) An Economic Assessment of Weed Control Strategies in No-Till Glyphosate-Resistant Soybean (Glycine max). Weed Technology, 14, 755-763. http://dx.doi.org/10.1614/0890-037X(2000)014[0755:AEAOWC]2.0.CO;2

\section{Abbreviations}

EPOST: early postemergence

LPOST: late postemergence

PRE: preemergence

POST: postemergence

WAA: weeks after herbicide application 